\title{
ASESMEN RESIKO BENCANA MENGGUNAKAN METODE KUALITATIF PADA DESA IMOGIRI
}

\author{
Imam Trianggoro Saputro \\ Dosen Program Studi Teknik Sipil, Universitas Muhammadiyah Sorong \\ Email : Imam.civil10@gmail.com
}

\begin{abstract}
Abstrak
Bencana alam merupakan suatu ancaman yang dapat menimpa suatu kawasan dimanapun berada. Ini tentunya harus menjadi perhatian yang penting dalam rangka upaya pengurangan resiko bencana. Desa Imogiri merupakan salah satu desa yang berlokasi di Yogyakarta, tepatnya kabupaten Bantul. Seperti yang diketahui, daerah Yogyakarta sering terjadi bencana seperti kekeringan, gempa bumi, letusan gunung berapi, dan lainnya. Pada penelitian ini mengasesmen resiko bencana tersebut. Metode yang digunakan adalah asesmen resiko bencana menggunakan metode kualitatif (Qualitative Risk Hazard Assessment). Parameter dan indikator penilaian yang digunakan mengacu pada British Columbia Provincial Emergency Program. Hasil dari penelitian menunjukkan bahwa resiko yang paling dominan pada daerah ini adalah bencana gempa bumi kemudian disusul oleh letusan/erupsi gunung berapi.
\end{abstract}

Kata Kunci : Asesmen Resiko Bencana, Qualitative Risk Hazard Assessment, Desa Imogiri

\section{Pendahuluan}

Desa Imogiri merupakan salah satu daerah di Bantul yang terkena dampak terhadap gempa Yogyakarta yang terjadi pada tanggal 27 mei 2006. Dan mengalami cukup banyak korban jiwa dan juga kerusakan struktur dan infrastruktur. Selain itu, gunung Merapi yang sering meletus merupakan suatu ancaman tersendiri bagi masyarakat Yogyakarta. Material vulkanik yang terbawa oleh angin dapat mengganggu kesehatan masyarakat dan juga perekonomian sekitar. Bencana lain pun terkadang terjadi seperti kekeringan maupun banjir. Hal ini tentunya diperlukan suatu asesmen dalam rangka mengidentifikasi bencana mana yang memiliki resiko paling tinggi.

Pengurangan resiko ini sangat penting sebagai langkah mitigasi. Upaya mitigasi perlu dilakukan untuk mengidentifikasi bencana yang akan terjadi dikemudian hari dengan mengambil langkah antisipasi. Hal ini dilakukan dalam rangka untuk mengurangi resiko yang ditimbulkan sehingga tingkat kerugian dan korban yang berjatuhan dapat diminimalisir (Saputro, 2018).

Ada beberapa metode untuk melakukan asesmen resiko bencana yaitu metode kualitatif, metode kuantitatif dan metode semi-kuantitatif. Metode-metode tersebut memiliki berbagai keunggulan masing-masing. Metode kualitatif merupakan metode yang paling simpel digunakan dalam asesmen resiko terhadap bencana. Pada metode ini indikator dapat mengekspresikan tingkat resiko dari bencana tersebut seperti: sangat rendah, rendah, sedang, tinggi, atau sangat tinggi. Indikator ini bergantung pada standar acuan para ahli yang dipakai.

Standar acuan yang dipakai pada penelitian ini adalah mengacu pada British Columbia Provincial Emergency Program. Terdapat beberapa aspek yang diperhitungkan dalam acuan ini diantaranya adalah kematian (fatality), terluka (injured), fasilitas vital (critical facilities), fasilitas umum pendukung (life-lines), kerusakan harta milik (property damage), lingkungan (environment), dampak ekonomi dan sosial (economics and sosial impacts). Berdasarkan datadata tersebut maka dapat disajikan data dalam bentuk matrikulasi resiko/Risk Matrix. 


\section{Tujuan}

Penelitian ini bertujuan untuk melakukan langkah asesmen resiko bencana yang mungkin terjadi di daerah Desa Imogiri, Kecamatan Imogiri, Bantul, Yogyakarta dengan mempertimbangkan beberapa bencana yang berpotensi pada daerah tersebut.

\section{Metode}

Metode yang digunakan pada penelitian ini mengikuti flowchart yang tersaji pada Gambar 1 di bawah ini.

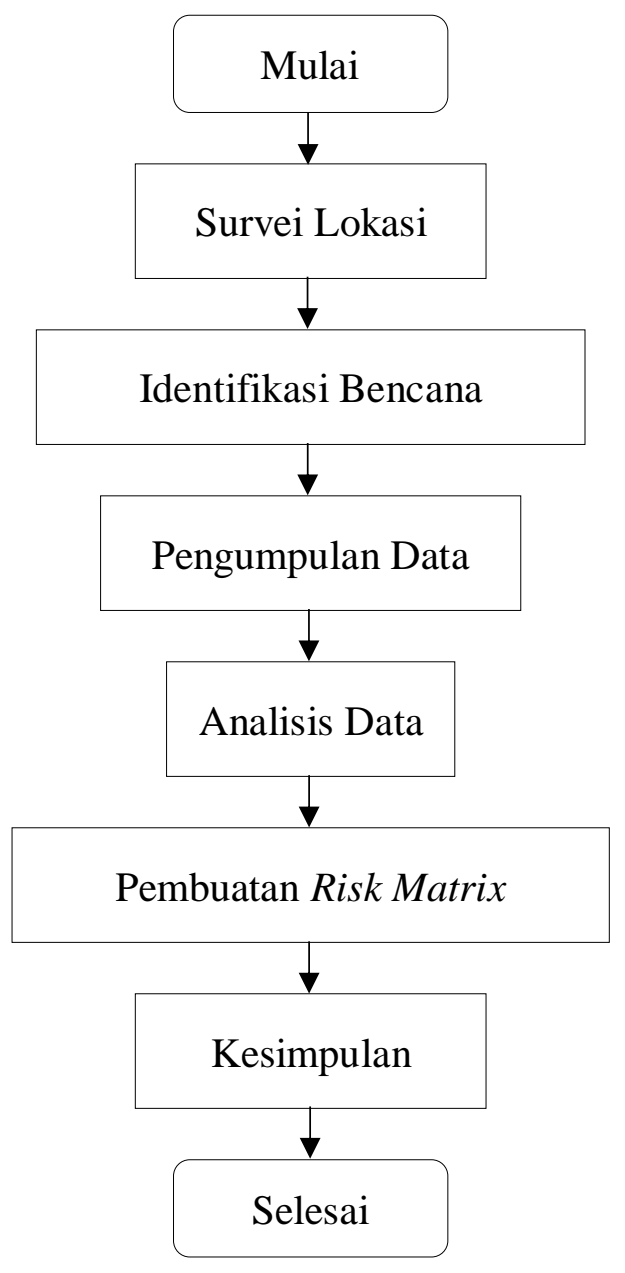

Gambar 1 Flowchart Metode Penelitian

\section{Analisis dan Pembahasan}

\section{Survei Lokasi dan identifikasi bencana}

Penelitian dilakukan pada daerah Desa Imogiri, Kecamatan Imogiri, Bantul, Yogyakarta. Desa ini memiliki luas sekitar 54,49 $\mathrm{km}^{2}$. Survei lokasi dilakukan untuk mengetahui kondisi tempat penelitian secara langsung. Selain itu, terdapat beberapa data sekunder yang diperlukan sebagai bahan pertimbangan dalam melakukan proses analisis. Data sekunder yang diperlukan seperti data penduduk daerah imogiri. Adapun tempat lokasi penelitian tersaji pada Gambar 2 berikut ini. 


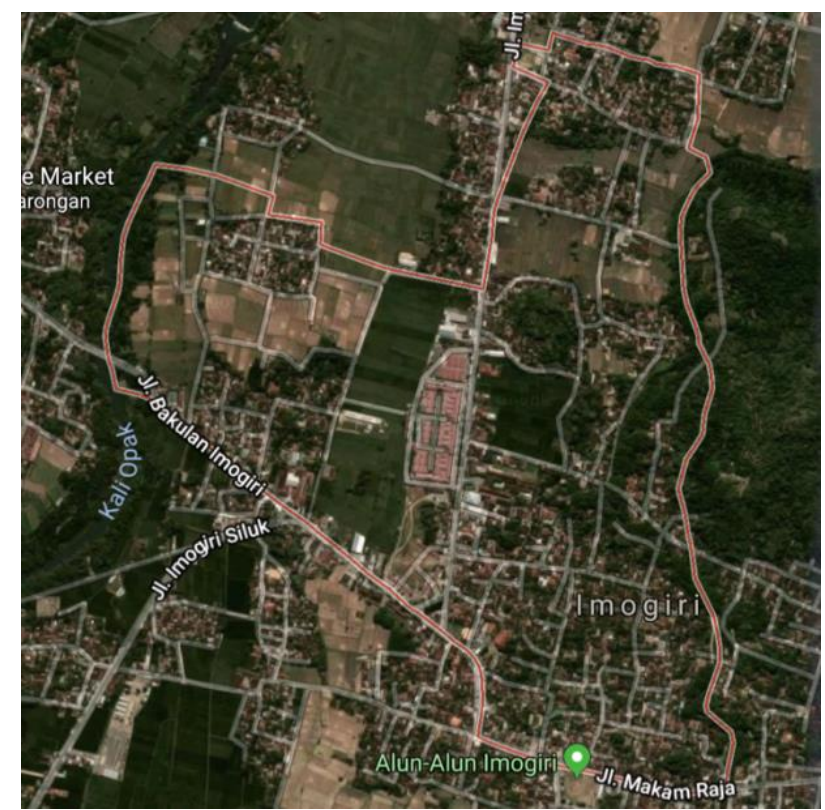

Gambar 2 Lokasi Penelitian (Google Map, 2018)

\section{Pengumpulan Data}

Pengumpulan data terkait penelitian terhadap desa imogiri dilakukan dengan mendatangi kantor desa imogiri untuk mengetahui jumlah penduduk dan penyebarannya menurut usia, dan tingkat pendidikan masyarakat sekitar. Setelah itu, melakukan wawancara langsung terhadap perangkat desa setempat. Kantor Desa Imogiri terlihat pada Gambar 3 berikut.

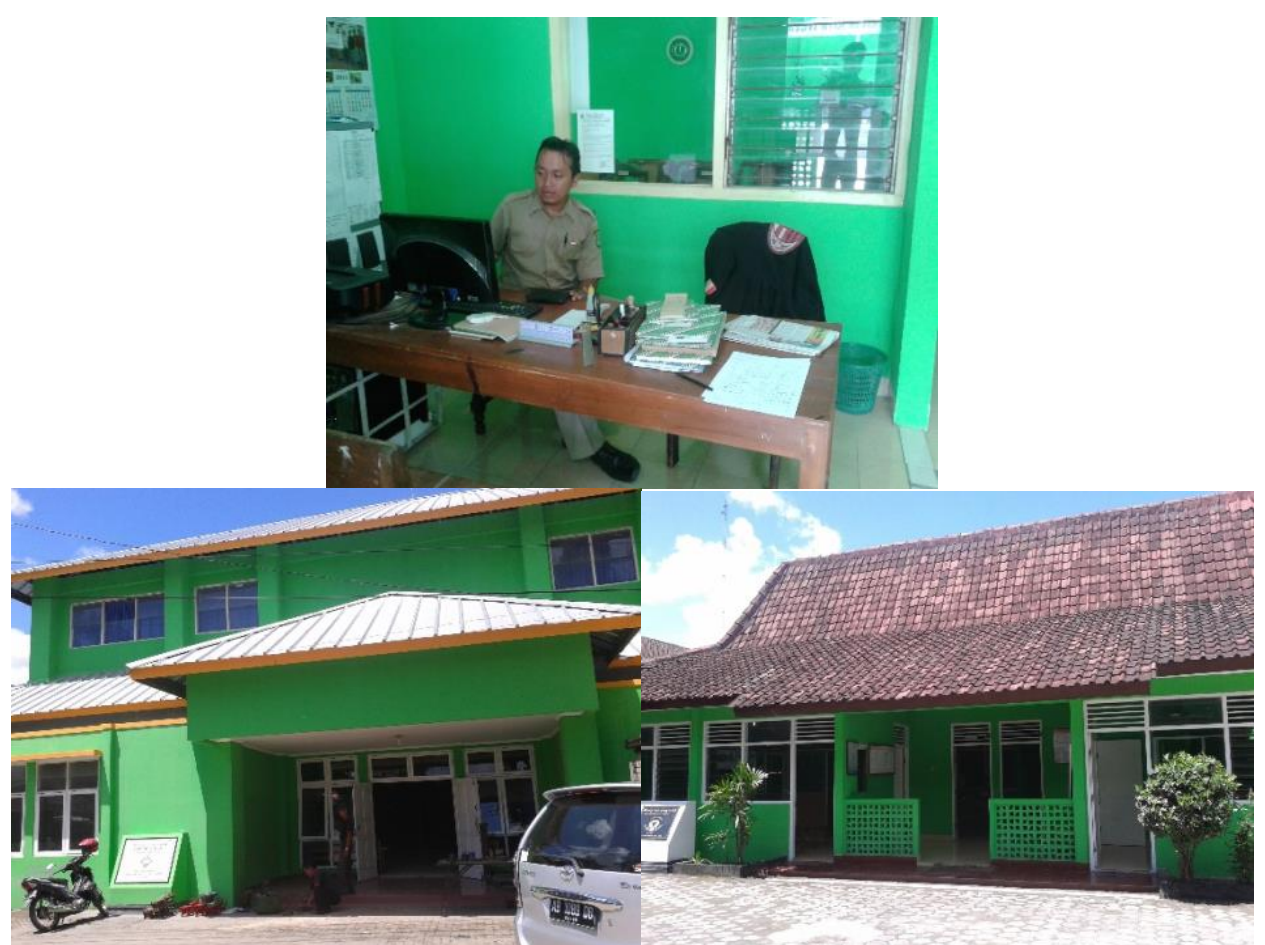

Gambar 3 Kantor Desa Imogiri 
Dari hasil survei yang dilakukan maka diperoleh beberapa data yaitu jumlah penduduk berdasarkan jenis kelamin pada Tabel 1, jumlah penduduk menurut pendidikan pada Tabel 2, jumlah penduduk menurut pekerjaan Tabel 3 dan Penyebaran penduduk perpedukuhan tahun 2013 pada Tabel 4.

Tabel 1 Jumlah Penduduk Berdasarkan Jenis Kelamin

\begin{tabular}{cccccc}
\hline \multirow{2}{*}{ No } & Pendukuhan & $\begin{array}{c}\text { Jenis Kelamin (Jiwa) } \\
\text { Laki- } \\
\text { Laki }\end{array}$ & Perempuan & $\begin{array}{c}\text { Jumlah } \\
\text { Total }\end{array}$ & $\begin{array}{c}\text { Jumlah } \\
\text { KK }\end{array}$ \\
\hline 1 & Dukuh & 366 & 435 & 801 & 270 \\
2 & Kerten & 600 & 566 & 1166 & 375 \\
3 & Paduresan & 400 & 445 & 845 & 277 \\
4 & Imogiri & 457 & 503 & 960 & 299 \\
& JUMLAH & $\mathbf{1 8 2 3}$ & $\mathbf{1 9 4 9}$ & $\mathbf{3 7 7 2}$ & $\mathbf{1 2 2 1}$ \\
\hline
\end{tabular}

Sumber : Data Administrasi Kabag Pembangunan Desa Imogiri Per 31 Desember 2013

Tabel 2 Jumlah Penduduk menurut Pendidikan

\begin{tabular}{cc}
\hline $\begin{array}{c}\text { Pendidikan } \\
\text { Terakhir }\end{array}$ & Jumlah \\
\hline TK & 108 \\
Sekolah Dasar & 519 \\
SLTP & 273 \\
SLTA & 259 \\
Akademi/D3 & 121 \\
Sarjana & 60 \\
\hline Sumber: Kantor Desa Imogiri
\end{tabular}

Tabel 3 Jumlah Penduduk menurut Pekerjaan

\begin{tabular}{cc}
\hline $\begin{array}{c}\text { Pendidikan } \\
\text { Terakhir }\end{array}$ & Jumlah \\
\hline PNS & 179 \\
Pegawai Swasta & 74 \\
ABRI & 23 \\
Wiraswasta/Pedagang & 443 \\
Tani & 232 \\
Buruh Tani & 203 \\
Pertukangan & 59 \\
Jasa & 25 \\
Pensiunan & 40 \\
Lainnya & 80 \\
\hline Sumber: Kantor Desa Imogiri
\end{tabular}


Tabel 4 Penyebaran Penduduk Per Pendukuhan Tahun 2013

\begin{tabular}{ccccccc}
\hline No & $\begin{array}{c}\text { Struktur } \\
\text { Umur }\end{array}$ & Dukuh & Kerten & Paduresan & Imogiri & Jumlah \\
\hline 1 & $0-14$ & 179 & 63 & 106 & 45 & 393 \\
2 & $15-24$ & 210 & 90 & 163 & 63 & 526 \\
3 & $25-49$ & 201 & 275 & 237 & 209 & 922 \\
4 & $>50$ & 195 & 81 & 198 & 220 & 694 \\
Jumlah Total & $\mathbf{7 8 5}$ & $\mathbf{5 0 9}$ & $\mathbf{7 0 4}$ & $\mathbf{5 3 7}$ & $\mathbf{2 5 3 5}$ \\
Presentase (\%) & $\mathbf{3 0 . 9 7}$ & $\mathbf{2 0 . 0 8}$ & $\mathbf{2 7 . 7 7}$ & $\mathbf{2 1 . 1 8}$ & $\mathbf{1 0 0 . 0 0}$ \\
\hline
\end{tabular}

Sumber : Pemetaan Swadaya Desa Imogiri 2013

Dari data-data diatas kemudian dilakukan penentuan parameter dan indikator yang akan digunakan untuk melakukan penilaian.

\section{Indikator Penilaian British Columbia Provincial Emergency Program}

Pada penelitian ini menggunakan indikator penilaian yang mengacu pada British Columbia Provincial Emergency Program yang memuat beberapa aspek seperti kematian (fatality), terluka (injured), fasilitas vital (critical facilities), fasilitas umum pendukung (lifelines), kerusakan harta milik (property damage), lingkungan (environment), dampak ekonomi dan sosial (economics and sosial impacts). Untuk penjelasan mengenai kriterianya tersaji pada Tabel 6 sampai Tabel 12. Adapun Tabel 5 menjelaskan kriteria tentang kemungkinan bencana tersebut terjadi.

Tabel 5 Kemungkinan Bahaya

\begin{tabular}{ccc}
\hline Skala & Keterangan & Kriteria \\
\hline 1 & Sangat tidak mungkin & $0 \%$ to $5 \%$ \\
2 & Tidak mungkin & $6 \%$ to $15 \%$ \\
3 & Sedang & $16 \%$ to $60 \%$ \\
4 & Mungkin & $61 \%$ to $60 \%$ \\
5 & Sangat mungkin & $>90 \%$ \\
\hline
\end{tabular}

Tabel 6 Korban Meninggal

\begin{tabular}{ccc}
\hline Skala & Keterangan & Kriteria \\
\hline 1 & Sangat Rendah & $0-4$ \\
2 & Rendah & $4-10$ \\
3 & Tinggi & $10-50$ \\
4 & Sangat Tinggi & $>50$ \\
\hline
\end{tabular}

Tabel 7 Korban Luka-luka

\begin{tabular}{ccc}
\hline Skala & Keterangan & Kriteria \\
\hline 1 & Sangat Rendah & $0-4$ \\
2 & Rendah & $4-50$ \\
3 & Tinggi & $50-2000$ \\
4 & Sangat Tinggi & $>2000$ \\
\hline
\end{tabular}


Tabel 8 Fasilitas Vital Kritis

\begin{tabular}{ccc}
\hline Skala & Keterangan & Kriteria \\
\hline 1 & Sangat Rendah & Relokasi sementara \\
2 & Rendah & Tutup dalam beberapa hari \\
3 & Tinggi & Kehilangan kemampuan hingga lebih 50\% \\
4 & Sangat Tinggi & Pulih dalam waktu lama \\
\hline
\end{tabular}

Tabel 9 Fasilitas Umum Pendukung

\begin{tabular}{ccc}
\hline Skala & Keterangan & Kriteria \\
\hline 1 & Sangat Rendah & Terganggu sementara \\
2 & Rendah & Terganggu selama beberapa hari \\
3 & Tinggi & Terganggu selama 1 minggu \\
4 & Sangat Tinggi & Tidak berfungsi dalam waktu lama \\
\hline
\end{tabular}

Tabel 10 Kerusakan Harta Milik

\begin{tabular}{ccc}
\hline Skala & Keterangan & Kriteria \\
\hline 1 & Sangat Rendah & Kerusakan minimal \\
2 & Rendah & Kerusakan ringan dan cakupan area lokal \\
3 & Tinggi & Kerusakan berat dan cakupan area lokal \\
4 & Sangat Tinggi & Kerusakan berat dan cakupan area luas \\
\hline
\end{tabular}

Tabel 11 Lingkungan

\begin{tabular}{ccc}
\hline Skala & Keterangan & Kriteria \\
\hline 1 & Sangat Rendah & Kerusakan minimal \\
2 & Rendah & Kerusakan ringan dan cakupan area lokal \\
3 & Tinggi & Kerusakan berat dan cakupan area lokal \\
4 & Sangat Tinggi & Kerusakan berat dan cakupan area luas \\
\hline
\end{tabular}

Tabel 12 Sosial dan Ekonomi

\begin{tabular}{ccc}
\hline Skala & Keterangan & Kriteria \\
\hline 1 & Sangat Rendah & Berdampak Sementara pada cakupan area lokal \\
2 & Rendah & Berdampak Sementara pada cakupan area luas \\
3 & Tinggi & Berdampak lama pada cakupan area luas \\
4 & Sangat Tinggi & Gangguan berdampak lama \\
\hline
\end{tabular}

Jenis bencana yang akan diperhitungkan pada asesmen ini adalah gempa bumi, letusan gunung, tsunami, tanah longsor, banjir dan kekeringan. Asesmen pada bencana tersebut dinilai dengan menggunakan motede Qualitative Risk Hazard Assessment.

Setelah menentukan parameter dan nilai yang akan digunakan kemudian langsung mengevaluasi lokasi Desa Imogiri. Berdasarkan hasil survey pengumpulan data wawancara terhadap perangkat desa setempat, maka data dapat disajikan seperti pada Tabel 13 sampai Tabel 15 berikut ini. 
Tabel 13 Hasil Pengumpulan Data

\begin{tabular}{lcccc}
\hline \multicolumn{1}{c}{ Bencana } & $\begin{array}{c}\text { Probabilitas } \\
\text { kejadian }\end{array}$ & Kematian & $\begin{array}{c}\text { Dampak/Konsekuensi } \\
\text { Luka- } \\
\text { Luka }\end{array}$ & Dampak ke fasilitas \\
\hline Gempa bumi & $16 \%$ to $60 \%$ & 44 & 4218 & Pulih dalam waktu lama \\
Gunung berapi & $61 \%$ to $60 \%$ & 0 & 0 & Tutup dalam beberapa hari \\
Tsunami & $0 \%$ to $5 \%$ & 0 & 0 & - \\
Longsor & $0 \%$ to $5 \%$ & 0 & 0 & - \\
Banjir & $61 \%$ to $60 \%$ & 0 & 0 & - \\
Kekeringan & $16 \%$ to $60 \%$ & 0 & 0 & - \\
\hline
\end{tabular}

Tabel 14. Hasil Pengumpulan data

\begin{tabular}{lcc}
\hline \multirow{2}{*}{ Bencana } & \multicolumn{2}{c}{ Dampak/Konsekuensi } \\
& Fasilitas umum pendukung & Kerusakan properti \\
\hline Gempa bumi & Terganggu sementara & Rumah dan kantor \\
Gunung berapi & Terganggu seminggu & - \\
Tsunami & - & - \\
Longsor & - & - \\
Banjir & Terganggu sementara & - \\
Kekeringan & - & - \\
\hline
\end{tabular}

Tabel 15. Hasil Pengumpulan data

\begin{tabular}{lcc}
\hline \multirow{2}{*}{ Hazard } & \multicolumn{2}{c}{ Dampak/Konsekuensi } \\
& Kerusakan minimal & Sosial \& ekonomi \\
\hline Gempa bumi & Gangguan berdampak lama \\
Gunung berapi & $\begin{array}{c}\text { Kerusakan berat dan } \\
\text { cakupan area lokal }\end{array}$ & Berdampak sementara \\
Tsunami & Kerusakan minimal & Berdampak sementara \\
Longsor & $\begin{array}{c}\text { Kerusakan ringan dan } \\
\text { cakupan area lokal }\end{array}$ & - \\
Banjir & $\begin{array}{c}\text { Kerusakan ringan dan } \\
\text { cakupan area lokal }\end{array}$ \\
Kekeringan & Kerusakan ringan dan & Berdampak sementara pada \\
& cakupan area lokal & cakupan area luas \\
\hline
\end{tabular}

Berdasarkan hasil asesmen terhadap beberapa parameter yang diperhitungkan maka dilakukan penilaian sesuai indikator yang sesuai dari masing-masing bencana yang dimasukkan. Ini dimaksudkan untuk melihat seberapa besar dampak yang ditimbulkan. Hasil penilaian dampak tersebut tersaji pada Tabel 16 berikut ini. 
Tabel 16 Penilaian dampak/konsekuensi

\begin{tabular}{|c|c|c|c|c|c|c|c|c|c|}
\hline \multirow[b]{2}{*}{ Bencana } & \multicolumn{3}{|c|}{ Kemungkinan } & \multicolumn{3}{|c|}{ Dampak/Konsekuensi } & \multirow[b]{2}{*}{ Lingkungan } & \multirow[b]{2}{*}{$\begin{array}{l}\text { Sosial \& } \\
\text { Ekonomi }\end{array}$} & \multirow[b]{2}{*}{$\mathrm{Jm}$} \\
\hline & Terjadi & Meninggal & Luka-luka & $\begin{array}{c}\text { Fasilitas } \\
\text { Vital }\end{array}$ & $\begin{array}{c}\text { Fasilitas } \\
\text { Umum }\end{array}$ & $\begin{array}{c}\text { Kerusakan } \\
\text { Harta }\end{array}$ & & & \\
\hline Gempa bumi & 3 & 3 & 3 & 4 & 1 & 4 & 1 & 4 & 23 \\
\hline Gunung berapi & 4 & 1 & 1 & 2 & 3 & 1 & 3 & 1 & 16 \\
\hline Tsunami & 1 & 1 & 1 & 1 & 1 & 1 & 1 & 1 & 8 \\
\hline Longsor & 1 & 1 & 1 & 1 & 1 & 1 & 2 & 1 & 9 \\
\hline Banjir & 4 & 1 & 1 & 1 & 1 & 1 & 2 & 1 & 12 \\
\hline Kekeringan & 3 & 1 & 1 & 1 & 1 & 1 & 2 & 2 & 12 \\
\hline
\end{tabular}

Tabel 16 menunjukkan hasil rekapitulasi dari asesmen terhadap bencana mungkin terjadi di daerah desa Imogiri, Kecamatan Imogiri, Bantul, Yogyakarta. Hasil skor penilaian dampak terbesar adalah pada bencana gempa bumi yaitu sebanyak 23 poin. Hal ini tentunya wajar mengingat di daerah Bantul sangat berdekatan dengan lokasi terdapatnya sesar Opak. Setelah itu potensi bencana yang besar berikutnya adalah berasal dari gunung berapi karena Merapi merupakan salah satu gunung yang paling aktif didunia. Tercatat siklus letusan merapi kurang lebih sekitar 5 tahunan melakukan erupsi. Nilai-nilai tersebut kemudian dibuat dalam suatu matrikulasi resiko/risk matrix. Matrikulasi Resiko bencana pada desa Imogiri tersaji pada Gambar 4 berikut.

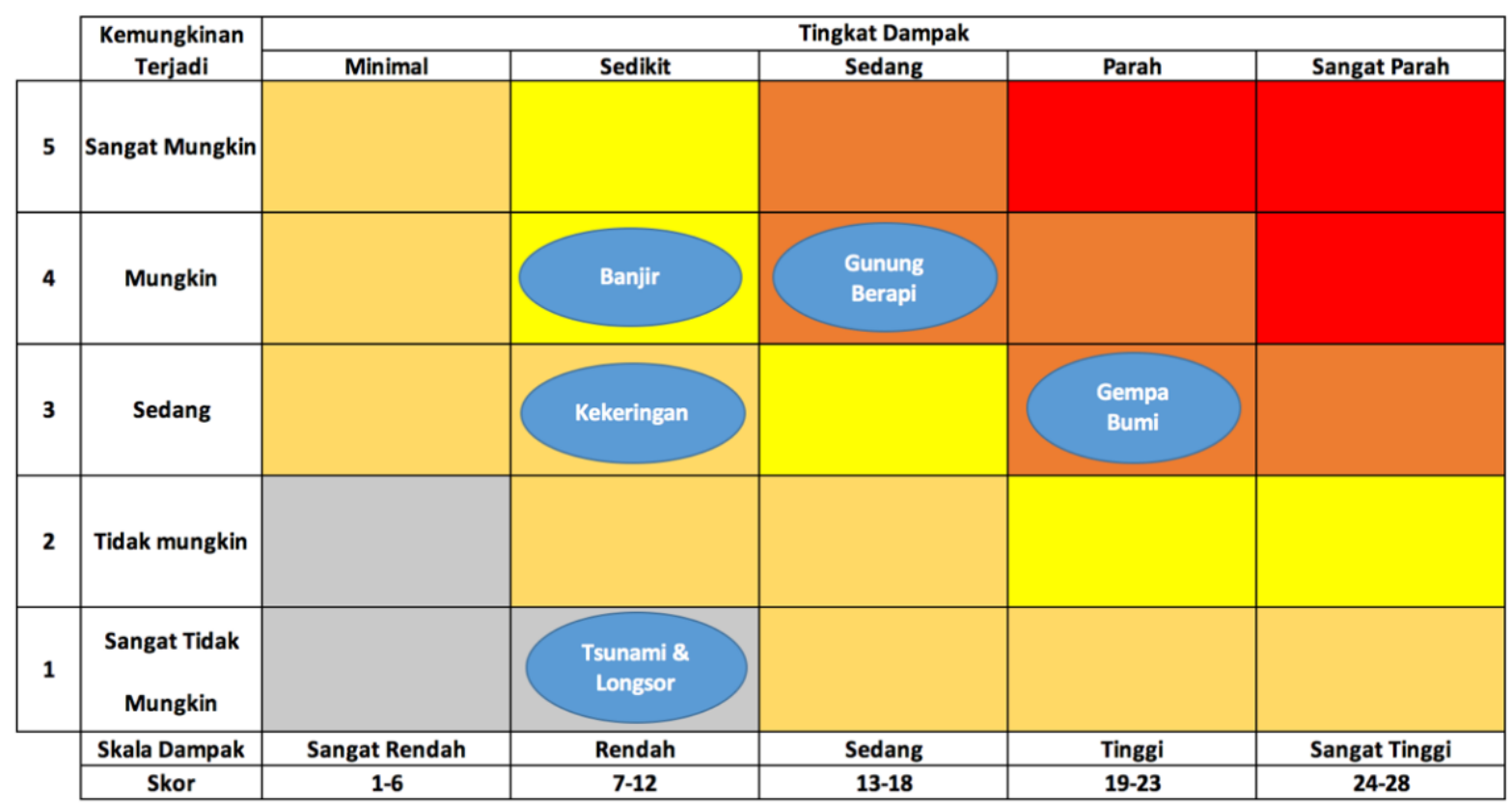

Gambar 4 Matrikulasi Resiko Bencana Desa Imogiri

\section{Kesimpulan}

Dari hasil asesmen resiko (risk assessment) dengan menggunakan metode qualitative risk hazard assessment diperoleh hasil bahwa pada desa Imogiri, bencana/hazard yang paling dominan atau terparah itu adalah gempa bumi. Salah satu penyebabnya karena dekat dengan sumber gempa sesar Opak. Gempa bumi pada tahun 2006 banyak menimbulkan korban jiwa dan juga kerusakan terhadap rumah warga maupun fasilitas pemerintahan. Dari pengambilan data diperoleh fakta bahwa korban banyak terjadi pada anak-anak dan juga orang lanjut usia. 
Hal ini dapat disimpulkan bahwa kerentanan terhadap anak-anak dan orang lanjut usia sangat tinggi. Sehingga perlu dilakukan sosialisasi bagaimana upaya penyelamatan apabila terjadi gempa bumi sehingga tidak banyak menimbulkan banyak korban jiwa karena menggingat sifat bencana gempa bumi yang tidak dapat diprediksi (unpredictable).

Letusan gunung berapi merupakan bencana yang terbesar kedua pada daerah ini. Letusan gunung berapi walaupun tidak banyak menimbulkan korban jiwa tetapi karena kala ulang (return period) yang terjadi sekitar 5 tahunan membuat gunung berapi merupakan suatu bencana/hazard yang harus serius ditangani. Bencana-bencana lain yang terjadi tidak terlalu signifikan mengingat kalau dibandingkan dengan bencana lainnya

\section{Daftar Pustaka}

Columbia, British (2004). Hazard, Risk, and Vurnerability Analysis Tool Kit. Provincial Emergency Program.

Saputro, I. T. (2018). Analisis Perbandingan Kurva Hazard Pada Kota Banda Aceh Dengan Sumber Gempa Sesar Seulimeum Dan Menggunakan Beberapa Fungsi Atenuasi.

Widodo (2013). Natural Hazard Risk Assessment. Bahan Kuliah. Universitas Islam Indonesia. Yogyakarta

https://www.google.com/map 